\title{
Isolation and Characterization of a Carmo-like Virus from Calibrachoa Plants
}

\author{
H.-Y. Liu and J. L. Sears, USDA-ARS, Salinas, CA 93905; and R. H. Morrison, Sakata Seed America, Inc, \\ Salinas, CA 93907
}

\begin{abstract}
Liu, H.-Y., Sears, J. L., and Morrison, R. H. 2003. Isolation and characterization of a carmo-like virus from Calibrachoa plants. Plant Dis. 87:167-171.

Spherical virus particles approximately 29 to $31 \mathrm{~nm}$ in diameter were isolated from Calibrachoa plants showing leaf mottling and chlorotic blotch symptoms. The virus was mechanically transmitted to Chenopodium amaranticolor, $C$. capitatum, $C$. quinoa, Nicotiana benthamiana, and $N$. clevelandii plants, but was not transmitted by green peach aphid (Myzus persicae), sweet potato whitefly (Bemisia tabaci), silverleaf whitefly (B. argentifolii), greenhouse whitefly (Trialeurodes vaporarium), or banded-wing whitefly (T. abutilonea). Virions contained a single species of single-stranded RNA of approximately $4.0 \mathrm{~kb}$ and a single capsid protein of approximately 41 $\mathrm{kDa}$. The double-stranded (ds)RNA pattern consistently revealed one major band of about 4.0 $\mathrm{kbp}$, and three minor dsRNA of approximately $3.1,1.6$, and $1.3 \mathrm{kbp}$. The virus-infected plants reacted with a homologous polyclonal antiserum in indirect enzyme-linked immunosorbent assay. The genome contained a sequence of a highly conserved motif of the RNA-dependent RNA-polymerase associated with the genus Carmovirus, and shared $94 \%$ identity with Carnation mottle virus (CarMV). However, the Calibrachoa virus and CarMV were distinct serologically and in host range. Based on the host ranges, particle morphology, dsRNA profile, properties of particles in sap, and features of the genome and protein, we concluded that the recently observed Calibrachoa disease is caused by a previously undescribed carmovirus on Calibrachoa plants. We propose to name this virus Calibrachoa mottle virus (CbMV).
\end{abstract}

Calibrachoa La Llave \& Lexarza (Solanaceae Jiss.) is becoming an important new horticultural plant. The first cultivars were released in the early 1990s (16). Wijsman and Jong $(20,21)$ first recognized Calibrachoa and Petunia as two distinct species based upon chromosome number; Calibrachoa spp. are $2 n=18$ chromosome and Petunia spp. are $2 n=14$ (17). Commercial reproduction and maintenance of Calibrachoa spp. is done by vegetative propagation.

A virus with spherical particles was isolated from Calibrachoa plants. The infected plant showed leaf mottling, chlorotic blotch, and interveinal yellowing symptoms. Based upon enzyme-linked immunosorbent assays (ELISA), the virus appeared to be unrelated to a number of known spherical viruses, including Arabis mosaic virus, Broad bean wilt virus, Carnation mottle virus (CarMV), Cucumber

Corresponding author: H.-Y. Liu

E-mail address: hliu@pw.ars.usda.gov

The mention of firm names or trade products in this article does not imply endorsement or recommendation by the United States Department of Agriculture over other firms or similar products not mentioned.

Accepted for publication 20 September 2002.

Publication no. D-2002-1120-02R

This article is in the public domain and not copyrightable. It may be freely reprinted with customary crediting of the source. The American Phytopathological Society, 2003. mosaic virus, Prunus necrotic ringspot virus, Tomato aspermy virus, Tomato bushy stunt virus, Tomato ringspot virus, Tobacco ringspot virus, or Tobacco streak virus. This study reports the host ranges, purification, characterization, serology, and certain properties of the virus for which we propose the name Calibrachoa mottle virus (CbMV). A preliminary report of portions of this research has been presented (11).

\section{MATERIALS AND METHODS}

Virus source. Leaves of symptomatic Calibrachoa plants were ground 1:5 (wt/vol) in $0.1 \mathrm{M}$ phosphate buffer, $\mathrm{pH} 7.0$, with a mortar and pestle. A small amount of Celite was added and Chenopodium quinoa Willd. plants were inoculated with this suspension by means of a cotton swab. Each single local lesion was subinoculated to $C$. quinoa. Local lesions were freeze dried for virus source.

Host range. Selected host plant species were mechanically inoculated as above. Inoculated plants were maintained for symptom development in a greenhouse under natural lighting with a temperature ranged of 26 to $32^{\circ} \mathrm{C}$.

Properties of virion in vitro. Systemically infected Nicotiana benthamiana Domin leaves were ground 1:2 (wt/vol) in sterile, distilled water in a mortar, and the sap was expressed through cheesecloth. Dilution endpoint was determined by inoculations with serial dilutions of crude sap to $10^{-7}$. Thermal inactivation point was determined using 1-ml aliquots heated to $40,50,60,70,80,90$, and $100^{\circ} \mathrm{C}$ for 10 min and then cooled in ice. Longevity in vitro was determined by using $1 \mathrm{ml}$ of crude sap pipetted into microfugetubes; the tubes were held at room temperature. One tube was used each week for an infectivity test. The infectivity tests were performed using $C$. quinoa plants as described above.

Insect transmission. Nonviruliferous green peach aphids (Myzus persicae (Sulzer)) were reared on radish (Raphanus sativus L.) (5). Sweet potato whiteflies (Bemisia tabaci (Gennadius)) A-biotype and B-biotype (also known as silverleaf whitefly, B. argentifolii Bellows and Perring) were reared on sweet potato (Ipomoea batatas (L.) Lam). Greenhouse whitefly (Trialeurodes vaporarium Westwood) and banded-wing whitefly (T. abutilonea Hald.) were reared on Physalis wrightii Gray (6). The virus source and test plants were $N$. benthamiana. Thirty insects were used for each test plant and eight test plants for each insect species. Transmission tests were done using the leaf-cage method (4) and each test was repeated three times.

Double-stranded RNA isolation. Double-stranded (ds)RNA was prepared according to Valverde et al. (18) using $7 \mathrm{~g}$ of Calibrachoa plant tissue for each sample and was analyzed by electrophoresis in a $1 \%$ agarose gel. dsRNAs were visualized by staining with ethidium bromide and photographed. dsRNA of Tobacco mosaic virus and Tomato bushy stunt virus were used as size markers.

Virion purification. Infected $N$. benthamiana plants were homogenized with two volumes of $0.1 \mathrm{M}$ phosphate buffer $(\mathrm{pH}$ 7.2) containing $0.01 \mathrm{M}$ glycine and $0.1 \%$ 2-mercaptoethanol and filtered through muslin cloth. Triton-X-100 (1\%) was added before stirring for $1 \mathrm{~h}$ at $4^{\circ} \mathrm{C}$. The extract was clarified with $1 / 10$ th volume of chloroform/butanol (1:1, vol/vol). Virions were precipitated by the addition of $6 \%$ polyethylene glycol (molecular weight $=$ 6,000 ) and $0.2 \mathrm{M}$ sodium chloride. The virions were further purified and concentrated by two cycles of differential centrifugation $\left(223,000 \times g\right.$ for $1 \mathrm{~h}$ at $\left.4^{\circ} \mathrm{C}\right)$, followed by centrifugation through a 10 to $35 \%$ sucrose density gradient in a Beckman SW28 Ti rotor $(82,700 \times g$ for $2 \mathrm{hr}$ at $4^{\circ} \mathrm{C}$ ). The tubes were fractionated with an ISCO density-gradient fractionator and analyzed in an ISCO UA-2 absorbance analyzer.

Electron microscopy. The purified virions were transferred to carbon-coated formvar grids and allowed to remain for 1 
min. After washing the grids with 30 drops of distilled water, grids were stained with $2 \%$ uranyl acetate containing bacitracin at $250 \mu \mathrm{g} / \mathrm{ml}$ (3). Images were generated and recorded with an EM 109 transmission electron microscope at $80 \mathrm{kv}$ (Carl Zeiss Inc., Thornwood, NY).

Preparation of antiserum. Antiserum to the purified virions was prepared in a New Zealand white rabbit. Equal volumes of purified virions and Freund's adjuvant were mixed and the rabbit was injected intramuscularly five times at 3 -week intervals. Freund's complete adjuvant and 500 $\mu \mathrm{g}$ of virus were used for the first injection. Incomplete adjuvant and $250 \mu \mathrm{g}$ of virus were used in all subsequent injections. The initial bleeding was 9 weeks after first injection, and was followed by four more bleedings at 3-week intervals. The titer of antisera were determined by microprecipitin tests (2).

Indirect ELISA. The indirect ELISA method was modified from Koenig (8). Polystyrene microtitration plates (Dynatech Laboratories, Inc., Chantilly, VA) were coated with test antigens at 200 $\mu \mathrm{l} /$ well (1:20, wt/vol) suspended in $0.05 \mathrm{M}$ carbonate coating buffer, $\mathrm{pH} 9.6$, containing $2 \%(\mathrm{wt} / \mathrm{vol})$ polyvinylpyrrolidone for 1 $\mathrm{h}$ at $37^{\circ} \mathrm{C}$, then blocked with $1 \%$ dry milk and $0.5 \%$ bovine serum albumin in phosphate buffered saline containing $0.05 \%$ Tween-20 for $30 \mathrm{~min}$ at room temperature. Whole CbMV rabbit antiserum was diluted 1:1000 and incubated for $1 \mathrm{~h}$ at $37^{\circ} \mathrm{C}$. After washing, alkaline phosphatase-labeled goat anti-rabbit immunoglobulin G (1:2000; Sigma-Aldrich, St. Louis) was added and incubated $1 \mathrm{~h}$ at $37^{\circ} \mathrm{C}$. Absorbance at 405 $\mathrm{nm}\left(\mathrm{A}_{405}\right)$ was measured 30 min after substrate $(0.6 \mathrm{mg} / \mathrm{ml})$ was added. Antigen and antiserum for CarMV were from the Agdia PathoScreen Kit (PSA 68000/0096; Agdia, Elkhart, IN).
Analysis of virion protein and nucleic acid. The viral capsid protein was prepared for electrophoresis by disrupting virions in $0.1 \mathrm{M}$ Tris-Cl, $\mathrm{pH} 6.8$, plus $4 \%$ sodium dodecyl sulfate (SDS), $10 \%$ glycerol, and 5\% 2-mercaptoethanol. Protein was reduced and alkylated with dithiothreital and iodoacetamide, respectively (10). Bromophenol blue was added as a tracking dye, and samples were analyzed by SDSpolyacrylamide gel electrophoresis (SDSPAGE) using the Laemmli system (9) in a mini slab unit (Idea Scientific, Corvallis, $\mathrm{OR})$ at $200 \mathrm{~V}$ of constant voltage for $1 \mathrm{~h}$ at room temperature. The 0.8 -mm-thick gel was composed of a 10-mm-high 5\% stacking gel above a 55-mm-high $12 \%$ resolving gel. Proteins were visualized by staining in 0.2\% Coomassie Brilliant Blue R-250, and the viral capsid protein molecular weight was estimated by comparing its mobility to protein molecular weight standards 14,300 to 200,000 Da. (Gibco BRL, Cat. No.16001-018; Life Technologies, Inc, Gaithersburg, MD).

Nucleic acids were extracted from purified virion preparations by using the RNeasy Mini Kit (QIAGEN Inc., Valencia, CA) according to the manufacturer's instructions. Nucleic acids were separated by electrophoresis using the glyoxal-dimethyl sulfoxide (DMSO) denaturing system (13). Electrophoresis was at room temperature in horizontal slab gels of $1.0 \%$ agarose for $1 \mathrm{~h}$ at $75 \mathrm{~V}$. Nucleic acids were stained with ethidium bromide, visualized over ultraviolet illumination, and photographed using Polaroid Type 665 positive-negative film.

Reverse transcription-polymerase chain reaction. Total RNA isolated from $100 \mathrm{mg}$ of healthy and CbMV-infected leaf tissue using RNAeasy RNA binding columns (Qiagen GmbH, Hilden, Germany), or viral RNA extracted from purified virion

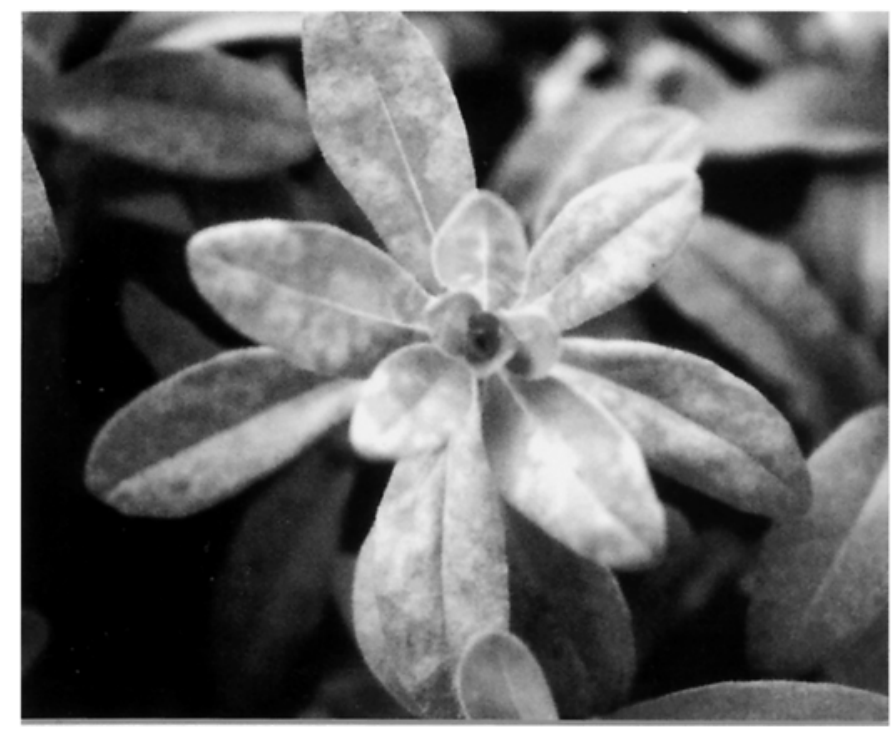

Fig. 1. Calibrachoa plant infected with Calibrachoa mottle virus showing leaf mottling and chlorotic blotch.

preparations described above, was denatured by heating at $95^{\circ} \mathrm{C}$ for $10 \mathrm{~min}$ and annealed with an antisense oligonucleotide primer (5'-GCAGTGTTCATGTCTCCGACATTCT- $\left.3^{\prime}\right)$. First-strand cDNA synthesis was performed in a $20-\mu \mathrm{l}$ reaction mixture using 200 units of M-MLV reverse transcriptase (Promega Corp., Madison, WI) according to the manufacturer's instructions. Second-strand synthesis and amplification of products were achieved by polymerase chain reaction (PCR) using the antisense oligonucleotide primer paired with $5^{\prime}$ primer (5'-GGGAGGAAAGACCGTAATGAAAGG-3'). The primer pairs were designed based on the Pelargonium flower-break virus RNA polymerase mRNA fragment (EMBL L34289) (14). Primers were synthesized by Gibco BRL. PCR reactions were carried out with 1 unit of Taq DNA polymerase (Promega Corp.), $1 \times$ reaction buffer $(10 \mathrm{mM}$ Tris- $\mathrm{HCl}, \mathrm{pH}$ 9.0, $50 \mathrm{mM} \mathrm{KCl}$, and $0.1 \%$ Triton $\mathrm{X}-100$ ), $3.0 \mathrm{mM} \mathrm{MgCl} 2,200 \mu \mathrm{M}$ each dNTP, 40 pmol each primer, and 5.0 $\mu \mathrm{l}$ of cDNA template in a final volume of $50 \mu \mathrm{l}$. The reaction mixture was heated to $94^{\circ} \mathrm{C}$ for 5 min; submitted to 30 cycles at $94^{\circ} \mathrm{C}$ for 45 $\mathrm{s}, 55^{\circ} \mathrm{C}$ for $1 \mathrm{~min}, 72^{\circ} \mathrm{C}$ for $1 \mathrm{~min}$; and finally heated to $72^{\circ} \mathrm{C}$ for $10 \mathrm{~min}$.

Cloning of PCR products and sequence analysis. Four independent reverse transcription (RT)-PCR-amplified DNA fragments were cloned into the pGEM-T Easy (Promega Corp.) according to the manufacturer's instructions. Recombinant plasmids containing cloned cDNAs were purified with a plasmid kit according to the manufacturer's instructions (QIAGEN Inc.). Four cloned DNA fragments in re-

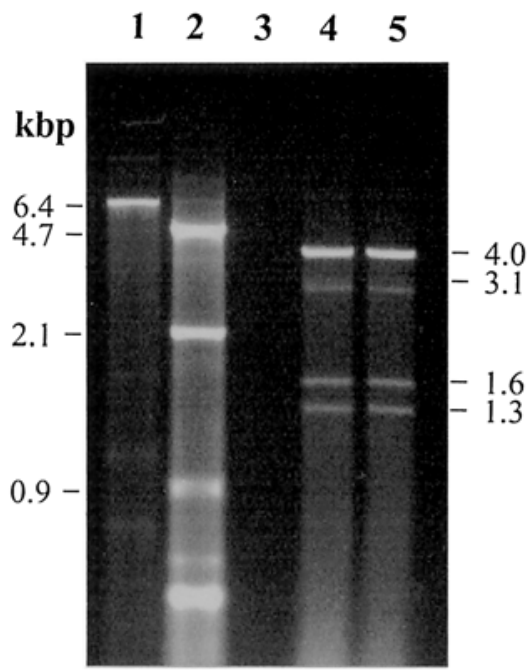

Fig. 2. Agarose gel electrophoresis of doublestranded (ds)RNA preparations from healthy (lane 3) and Calibrachoa mottle virus-infected Calibrachoa plants (lanes 4 and 5). Molecular markers are dsRNAs from Tobacco mosaic virus (lane 1) and Tomato bushy stunt virus (lane 2). Numbers indicate sizes (kbp) of molecular markers. The $1 \%$ agarose gel was run at $75 \mathrm{~V}$ for $1.5 \mathrm{~h}$. 
combinant plasmids were sequenced on both strands at the University of Florida Interdisciplinary Center for Biotechnology Research DNA Sequencing Core Laboratory (Gainesville) using universal M13forward and M13-reverse primers.

\section{RESULTS}

Symptoms and host range. Naturally infected Calibrachoa plants showed leaf mottling and chlorotic blotch (Fig. 1), but some CbMV-infected plants of several other cultivars were symptomless throughout their growth.

Plants susceptible to CbMV infection by mechanical inoculations were Chenopodiaceae: Chenopodium amaranticolor Coste \& Reyn., chlorotic local lesions; C. capitatum (L.) Asch., systemic vein clearing, stunting, and leaf distortion; C. quinoa Willd., chlorotic local lesions; Solanaceae: Nicotiana benthamiana Domin, vein clearing and systemic leaf mottling; and $N$. clevelandii Gray, systemic leaf mottling. Plants not susceptible to CbMV infection by mechanical inoculations were Amaranthaceae: Gomphrena globosa L.; Caryophyllaceae: Dianthus caryophyllus L.; Cruciferae: Brassica oleracea var. botrytis L., Capsella bursa-pastoris (L.) Medic.; Chenopodiaceae: Atriplex semibaccata R. Br., Beta macrocarpa Guss., B. vulgaris L., Chenopodium murale L., and Spinacia oleracea L.; Compositae: Picris echioides L. and Sonchus oleraceus L.; Cucurbitaceae: Citrullus vulgaris Schrad, Cucumis melo L., C. sativus L., and Cucurbita pepo L.; Leguminosae: Phaseolus vulgaris L.; Malvaceae: Gossypium hirsutum L.; So- lanaceae: Capsicum annuum L., Datura stramonium L., Lycopersicon esculentum Mill., Nicotiana glutinosa L., N. tabacum L., Petunia hybrida Vilm., Physalis floridana Rybd., and P. wrightii Gray.

Properties of CbMV in vitro. CbMV lost infectivity when heated for $10 \mathrm{~min}$ at $80^{\circ} \mathrm{C}$ but not $70^{\circ} \mathrm{C}$, diluted to $10^{-6}$ but not $10^{-5}$. CbMV remained infective after storage at room temperature for more than 12 weeks.

Insect transmission. $\mathrm{CbMV}$ isolates were not transmitted by green peach aphid (Myzus persicae), sweet potato whiteflies (Bemisia tabaci A-biotype and B-biotype), greenhouse whitefly (T. vaporarium), and banded-wing whitefly (T. abutilonea).

dsRNA analysis. Electrophoretic analysis of dsRNAs isolated from CbMV-infected Calibrachoa plants consistently revealed one major dsRNA and three mi- nor dsRNAs (Fig. 2, lanes 4 and 5) that were not present in healthy control plants (Fig. 2, lane 3). Based on their electrophoretic mobilities, the approximate size of the major dsRNA was $4.0 \mathrm{kbp}$; the minor dsRNAs were $3.1,1.6$, and $1.3 \mathrm{kbp}$, respectively.

Virion purification. Partially purified preparations from CbMV-infected $N$. benthamiana plants revealed a single lightscattering band (32 to $35 \mathrm{~mm}$ below the meniscus) following sucrose density gradient centrifugation, whereas similar components were not present in preparations from healthy $N$. benthamiana. When this zone was mechanically inoculated to $N$. benthamiana plants, the same symptoms as CbMV infection were obtained. Virions concentrated by ultracentrifugation gave an absorbance profile characteristic of nucleoproteins with a maximum absorbance

Table 1. Indirect enzyme-linked immunosorbent assay (absorbance at $405 \mathrm{~nm}$ ) values obtained with leaf extracts $(1: 20 \mathrm{wt} / \mathrm{vol})$ from Calibrachoa mottle virus (CbMV)- or Carnation mottle virus (CarMV)-infected plants

\begin{tabular}{lcc}
\hline & \multicolumn{2}{c}{ Antiseruma $^{\mathbf{a}}$} \\
\cline { 2 - 3 } Test plants & CbMV-As $^{\mathbf{b}}$ & CarMV-AS $^{\mathbf{c}}$ \\
\hline Healthy Calibrachoa plants & 0.120 & 0.093 \\
CbMV-infected Calibrachoa plants & $1.368^{*}$ & 0.101 \\
Healthy Chenopodium quinoa & 0.118 & 0.107 \\
CbMV-infected C. quinoa & $2.014^{*}$ & 0.109 \\
CarMV-infected C. quinoa & 0.103 & $0.667^{*}$ \\
Purified CbMV $(0.12 \mu \mathrm{g} / \mathrm{ml})$ & $1.645^{*}$ & 0.087 \\
Sample buffer & 0.107 & 0.089 \\
\hline
\end{tabular}

a Asterisk (*) indicates positive reactions (greater than $3 \times$ negative mean).

${ }^{\mathrm{b}} \mathrm{CbMV}$ antiserum was diluted 1:1000 and alkaline phosphatase-labeled goat anti-rabbit immunoglobulin $\mathrm{G}$ was diluted 1:2000. Each value is the mean of four replicates.

${ }^{c}$ Carnation mottle virus PathoScreen Kit (PSA 68000/0096) from Agdia, Inc. (Elkhart, IN).

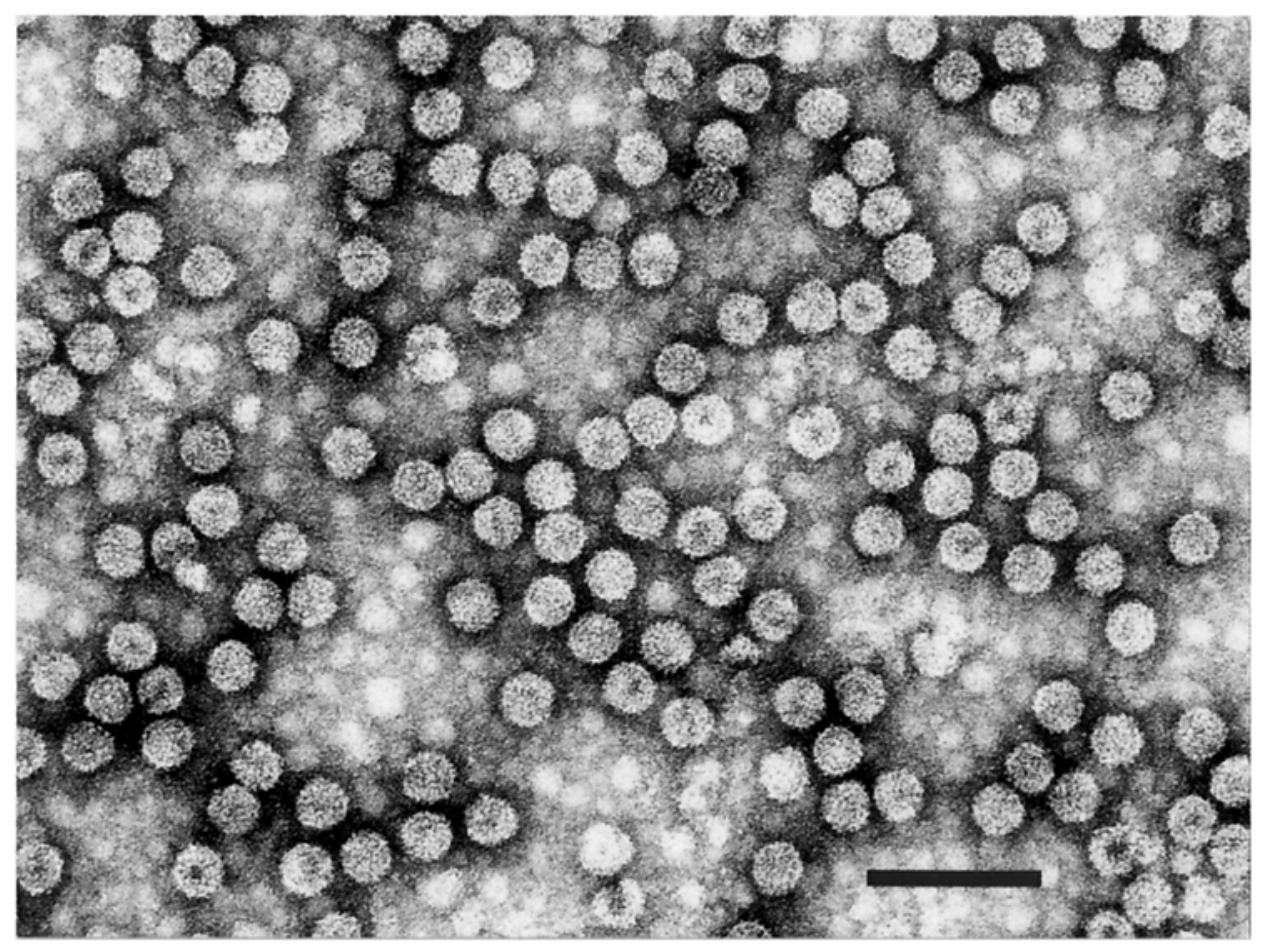

Fig. 3. Electron micrograph of purified virions of Calibrachoa mottle virus stained with $2 \%$ uranyl acetate containing bacitracin at $250 \mu \mathrm{g} / \mathrm{ml}$. The bar represents $100 \mathrm{~nm}$. 
at $258 \mathrm{~nm}$ and $\mathrm{A}_{260} / \mathrm{A}_{280}$ of 1.38 (uncorrected for light-scattering). Yield of purified virions were approximately 20 $\mathrm{mg} / 100 \mathrm{~g}$ of tissue using the extinction coefficient of 4.5 given for Tomato bushy stunt virus (12).

Electron microscopy. Examination of purified virus consistently revealed isometric particles of approximately 29 to $31 \mathrm{~nm}$ (Fig. 3). Virus particles stained readily in uranyl acetate and maintained their particle integrity without fixation.

Serology. The antiserum made to purified CbMV reacted with CbMV-infected plant tissue and purified CbMV, but not with extracts from healthy plants in indirect ELISA tests (Table 1). The titer of the antiserum was $1 / 128$ in microprecipitin tests.

Analysis of virion proteins and nucleic acid. A single virion capsid protein of approximately $41.0 \mathrm{kDa}$ was resolved by SDS-PAGE on $12 \%$ polyacrylamide gels (Fig. 4). No proteins were found in similar preparations from healthy plants (data not shown).

A single species of single-stranded RNA was seen when CbMV virion RNA was run in $1 \%$ agarose gels using the glyoxalDMSO denaturing system (Fig. 5). By comparing the mobility of CbMV RNA with the RNA ladder, the CbMV RNA was approximately $4.0 \mathrm{~kb}$.

RT-PCR. A region at the $5^{\prime}$ end of the genomic RNA corresponding to nucleotides of highly conserved motifs of carmovirus-related RNA-dependent RNA

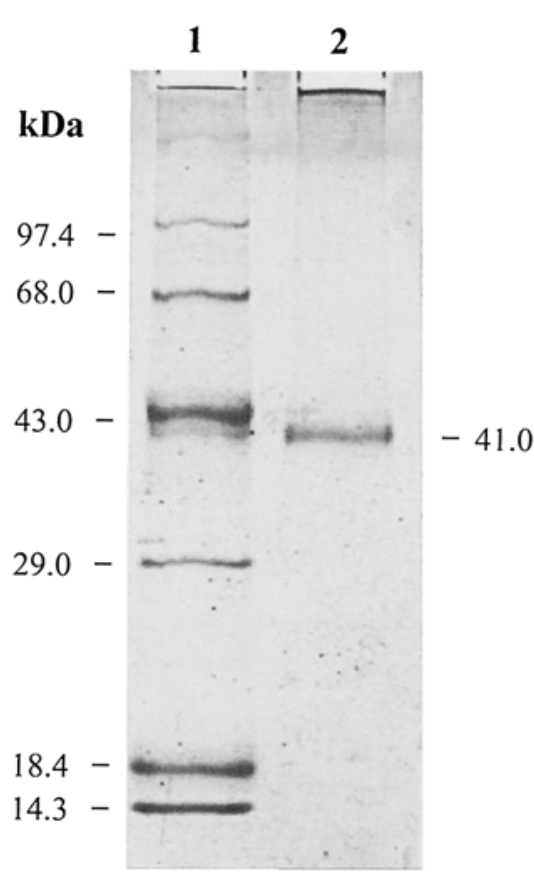

Fig. 4. Sodium dodecyl sulfate-polyacrylamide (12\% acrylamide) slab gel showing virion capsid protein. Lane 1, molecular weight standards in order of decreasing mass: phosphorylase B, bovine serum albumin, ovalbumin, carbonic anhydrase, B-lactoglobulin, and lysozyme. Lane 2, Calibrachoa mottle virus. polymerase gene was amplified by RTPCR. The product size of about $300 \mathrm{bp}$ was expected (Fig. 6, lanes 3 and 4). No products were found in similar preparations from healthy plants (Fig. 6, lane 2).

Cloning and sequencing. RT-PCR-amplified DNA fragments were cloned into pGEM-T Easy. More than 50 white colonies were picked; approximately $60 \%$ contained cloned cDNA. The nucleotide sequence of clone pCbMV48 revealed a cDNA insert of 253 nucleotides (GenBank accession no. AF535148). A computerassisted search of the GenBank database using the Blast algorithm (1) with this sequence revealed $94 \%$ homology to Carnation mottle virus (X02986). In comparison, in the same region of other carmoviruses, including Pelargonium flower break virus (Z28395), Cardamine chlorotic fleck virus (L16015), Saguaro cactus virus (U72332), Melon necrotic spot virus (D12536), and Turnip crinkle virus (M22445), the nucleotide identities to CbMV to these viruses were $63,55,54,52$, and $32 \%$, respectively.

\section{DISCUSSION}

The virus isolated from Calibrachoa plants shared several features with virus species of the genus Carmovirus, family Tombusviridae, including particle morphology, dsRNA profile, properties of particles in sap, and features of the genome and proteins (19). Comparison with the genus Carmovirus highly conserved RNA-

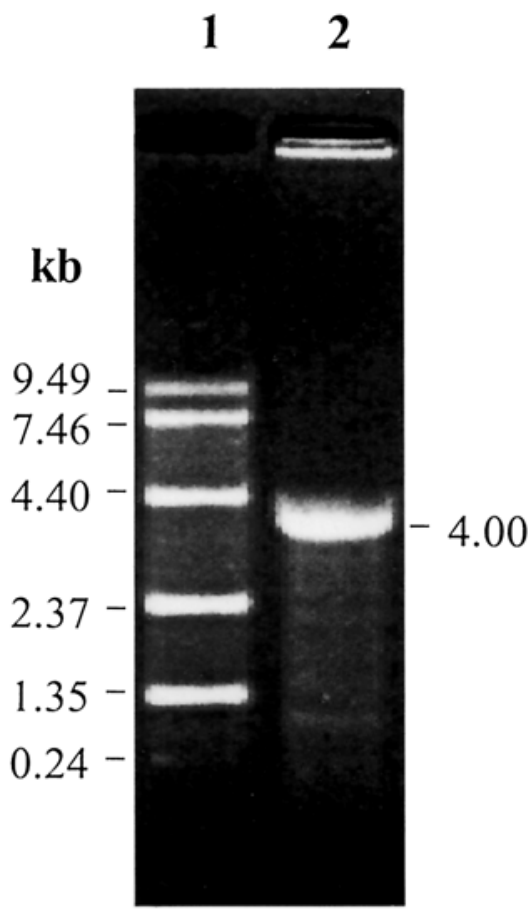

Fig. 5. A $1 \%$ agarose gel showing virion RNA after denaturation with glyoxal and dimethyl sulfoxide and subsequent electrophoresis. Lane 1, BRL RNA ladder, the molecular weight in kilobases $(\mathrm{kb})$ shown in the left. Lane 2, Calibrachoa mottle virus. dependent RNA polymerase gene sequence revealed that CbMV has $94 \%$ identity with CarMV. However, their host ranges differed $(7,15)$ and they were serologically distinct (Table 1).

The symptoms of CbMV on Calibrachoa plants can vary from severe mottling (Fig. 1) to symptomless depending upon cultivars and growing conditions. CbMV commonly may occur in Calibrachoa spp., even though plants appear visually healthy. If Calibrachoa plants were co-infected with Tobacco mosaic virus, the infected plants showed severe stunting and interveinal yellowing.

Commercial reproduction of Calibarchoa plants and maintenance of genetic mother stock are done by means of vegetative propagation, because reproduction through seed is difficult. CbMV was not transmitted by the five common insect vectors of viruses, but was easily mechanically transmitted. Thus, CbMV can be readily propagated along with its host. To eliminate CbMV from Calibrachoa stocks, virus-free mother stock plants must be obtained and maintained using good sanitary nursery practices.

Our data showed that indirect ELISA and specific polyclonal antibodies will be useful for the rapid identification and indexing of Calibrachoa plants for CbMV. ELISA should be an efficient tool to aid in indexing and maintenance of virus-free

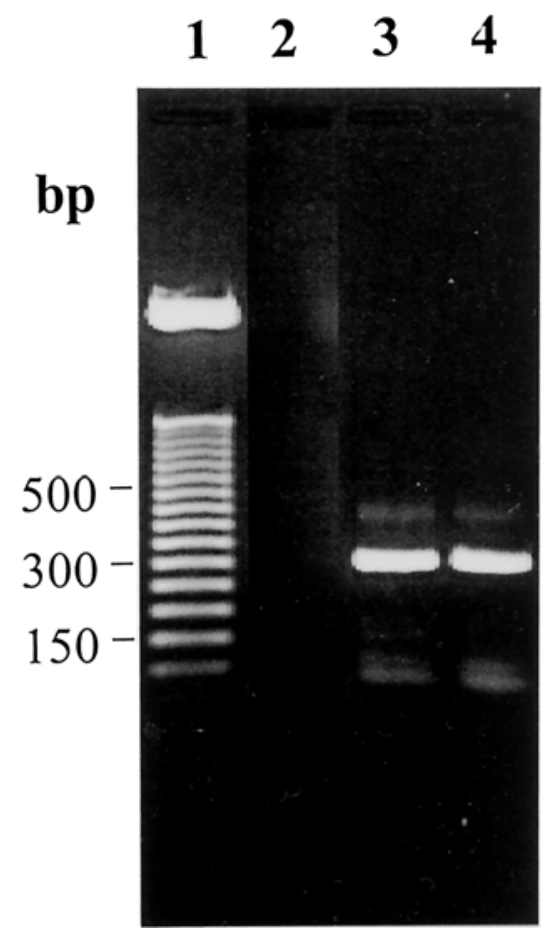

Fig. 6. A $1.5 \%$ agarose gel showing the products of reverse transcription-polymerase chain reaction from Calibrachoa mottle virus (CbMV)-infected Nicotiana clevelandii plants and CbMV virion RNA. Lane 1, BRL 50 base pair ladder. Lane 2, healthy $N$. clevelandii. Lane 3, CbMV-infected N. clevelandii. Lane 4, purified CbMV virion RNA. 
mother stock and commercial planting stock in a healthy nursery management program.

Based on our results, we concluded that the recently observed Calibrachoa disease was caused by a previously undescribed carmovirus. We propose to name this virus Calibrachoa mottle virus (CbMV). Further sequencing of the CbMV genome will be required to determine the relationship between CbMV and other members of the carmovirus genus.

\section{ACKNOWLEDGMENTS}

We thank E. Mojica for providing test materials; K. Schlueter for excellent technical assistance; and J. D. McCreight, H.-T. Hsu, and B.-M. Wu for critical review of the manuscript.

\section{LITERATURE CITED}

1. Altschul, S. F., Madden, T. L., Schaffer, A. A., Zhang, J., Zhang, Z., Miller, W., and Lipman, D. J. 1997. Gapped BLAST and PSI-BLAST: a new generation of protein database search programs. Nucleic Acids Res. 25:3389-3402.

2. Ball E. M. 1990. Microprecipitation (virus) and micro-agglutination (bacteria). Pages 153-160 in: Serological Methods for Detection and Identification of Viral and Bacterial Plant Pathogens. R. Hampton, E. Ball, and S. De Boer, eds. American Phytopathological Society Press, St. Paul, MN.

3. Christie S. R., Purcifull D. E., Crawford W. E., and Ahmed N. A. 1987. Electron microscopy of negatively stained clarified viral concentrates obtained from small tissue samples with appendices on negative staining tech- niques. Bull. 872. Inst. Food Agric. Sci. Univ. Fla. Gainesville.

4. Cohen S., and Harpaz, I. 1964. Periodic, rather than continual, acquisition of a new tomato virus by its vector, the tobacco whitefly (Bemisia tabaci Genn.). Entomol. Exp. Appl. 7:155-166.

5. Duffus, J. E. 1964. Host relationships of Beet western yellows virus strains. Phytopathology 54:736-738.

6. Duffus, J. E. 1965. Beet pseudo-yellows virus, transmitted by the greenhouse whitefly (Trialeurodes vaporariorum). Phytopathology 55:450-453.

7. Hollings M., and Stone O. M. 1970. Carnation mottle virus. CMI/AAB Descr. Plant Viruses No. 7.

8. Kloenig, R. 1981. Indirect ELISA methods for the broad specificity detection of plant viruses. J. Gen. Virol. 55:53-62.

9. Laemmli, U. K. 1970. Cleavage of structural proteins during the assembly of the head of bacteriophage T4. Nature (Lond.) 27:680-685.

10. Lane, L. C. 1978. A simple method for stabilizing protein-sulfhydryl groups during SDSgel electrophoresis. Anal. Biochem. 86:655664.

11. Liu H.-Y., Sears J. L., and Morrison R. H. 2001. First report of a spherical virus isolated from Calibrachoa plant. (Abstr.) Phytopathology 91:S55.

12. Martelli G. P., Quacquarelli A., and Russo M. 1971. Tomato bushy stunt virus. CMI/AAB Descr. Plant Viruses No. 69.

13. McMaster G. K., and Carmichael G. C. 1977. Analysis of single-and double-stranded nucleic acids on polyacrylamide and agarose gels by using glyoxal and acridine orange. Proc. Natl. Acad. Sci. USA 74:4835-4838.
14. Morozov S. Y. U., Ryabov E. V., Leiser R. M and Zavriev S. K. 1995. Use of highly conserved motifs in plant virus RNA polymerases as the tags for specific detection of carmovirus-related RNA-dependent RNA polymerase genes. Virology 207:312-315.

15. Morris T. J., and Carrington J. C. 1988. Carnation mottle virus and viruses with similar properties. Pages 73-112 in: The Plant Viruses, Vol. 3. Polyhedral Virions with Monopartite RNA Genome. Koenig R, ed. Plenum Press, New York.

16. Poehlman, K. 1997. Chimes like petunias. Greenhouse Grower. Dec. 1997:114.

17. Stehman J. R., and Semir J. 1997. A new species and new combinations in Calibrachoa Novon 7:417-419.

18. Valverde R. A., Nameth S. T., and Jordan R. L. 1990. Analysis of double-stranded RNA for plant virus diagnosis. Plant Dis. 74:255-258.

19. Van Regenmortel, M. H. V., Fauquet C. M., Bishop D. H. L., Carstens, E. B., Estes, M. K., Lemon, S. M., Maniloff, J., Mayo M. A McGeoch, D. J., Pringle, C. R., and Wickner, R. B., eds. 2000. Pages 801-805 in: Virus Taxonomy. Seventh Rep. Int. Committee for the Taxonomy of Viruses. Genus Carmovirus. Academic Press, London and San Diego, CA

20. Wijsman, H. J. 1990. On the interrelationships of certain species of Petunia. VI. New names for the species of Calibrachoa formerly included into Petunia. Acta Bot. Neerl. 39:101102.

21. Wijsman H. J., and Jong J. H. 1985. On the interrelationships of certain species of Petunia. IV. Hybridization and nomenclatural consequences in the Petunia group. Acta Bot. Neerl. 34:337-349. 